\section{Los gitanos}

\section{Gypsies}

$\mathrm{E}$ l origen del pueblo gitano estuvo rodeado durante largo tiempo por el misterio y la leyenda, posiblemente inducida por ellos mismos como un modo de protegerse de la persecución a la que han sido sometidos.

Si bien la denominación aceptada para esta etnia es pueblo Romaní, durante muchos años se creyó que provenían de Egipto, por lo cual se les denominó “egiptanos”, vocablo que luego derivó en "gitanos”. Así, Andrew Boorde, académico inglés del siglo dieciséis, estudió su dialecto creyéndolo la lengua egipcia antigua.

También se pensó que provenían de Frigia, actual Turquía, de una secta denominada “intocables”, que en griego se conocían como “Atzinganos”, de donde derivó el apelativo de "Zíngaros” y sus derivaciones en distintas lenguas europeas.

Otros orígenes legendarios los han considerado desde una tribu de Israel extraviada en Egipto, hasta los forjadores de los clavos de Cristo, condenados a errar por el mundo.

Lamentablemente, los fríos estudios genéticos y lingüísticos modernos han establecido que es un pueblo originario de la región de Punjab, en la frontera entre India y Pakistán y que pertenecían a una casta inferior, denominada Dom, que fonéticamente derivó luego en Rom o Romaní.

Lo que es un misterio es el motivo de su diáspora, la que se produjo aproximadamente en el siglo X posiblemente como prisioneros
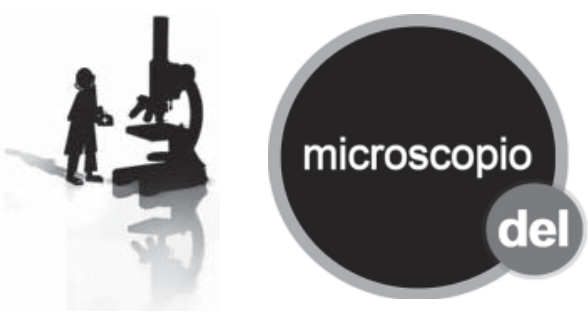

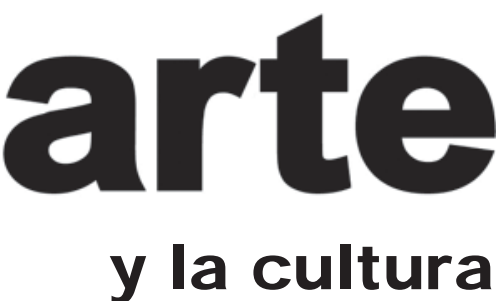

y luego esclavos de los musulmanes que conquistaron el Punjab.

El caso es que bajo el imperio de Mahmud de Ganzi, los Rom se desplazaron desde la India, a Pakistán, Irán, Afganistán y Turquía.

Su carácter nómade, su escaso interés por el pastoreo y la agricultura, su habilidad en el trabajo de los metales, y su cultivo de la danza, la música y la magia, hizo que se constituyeran en un pueblo migrante, que vivía de sus artes adivinatorias, sus espectáculos y el comercio ambulante. Incluso durante el imperio Bizantino, estos extranjeros, llamados “Atzingani”, fueron empleados por sus hechicerías y artes de magia hasta por el mismo Constantino.

De ahí a cruzar hacia los Balcanes había un paso, y ese se dio en el siglo XIV, hacia Rumania, Serbia y Bulgaria. Otro grupo se dirigió al sur y de manera incansable recorrieron el norte de África hasta entrar a España por Gibraltar.

Durante los siglos siguientes se dispersaron por toda Europa, llegando a las islas británicas e incluso Finlandia y Suecia.

A América llegaron procedentes mayoritariamente de Serbia a comienzos del siglo XX. En Chile la comunidad Romaní es casi totalmente de origen serbio y el grupo Rom es el más numeroso. Ellos llaman a su lengua Romané jorajané.
El aporte del pueblo gitano a las artes y la cultura es enorme, y personajes como Yul Briner, Michael Caine, Charles Chaplin y Helen Mirren, entre los actores, así como el director de orquesta Sergiuo Celibidache, y el músico de jazz Django Reinhardt tienen sangre gitana.

Los gitanos han sido objeto de las mayores persecuciones y genocidios, en especial durante el siglo $\mathrm{XX}$, y sin embargo han podido sobrevivir como pueblo y cultura, a pesar del desprecio y la hostilidad de las poblaciones autóctonas, las que al parecer no son capaces de aceptar que un grupo humano viva de una manera auténticamente libre.

\section{Referencias}

1.- Godwing P. Gypsies, the outsiders. National Geographic Magazine. April 2001; 72-101.

2.- Primeros gitanos en Chile. http://www. gitanoschile.cl/web (acccedido el 26 de agosto de 2011).

3.- Famous Gypsies. http://www.imninalu.net/ famousgypsies.htm_(accedido el 26 de agosto de 2011).

Ernesto Payá G. Hospital de Carabineros, Santiago

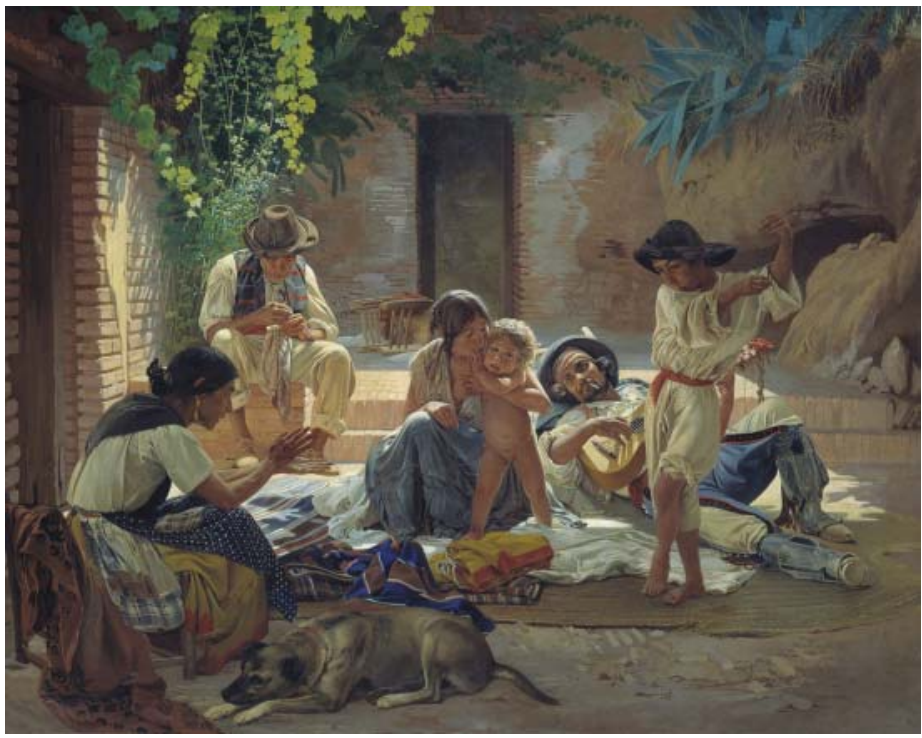

Figura 1. Yevgraf Sorokin: Familia gitana española. Óleo sobre tela; 1853.

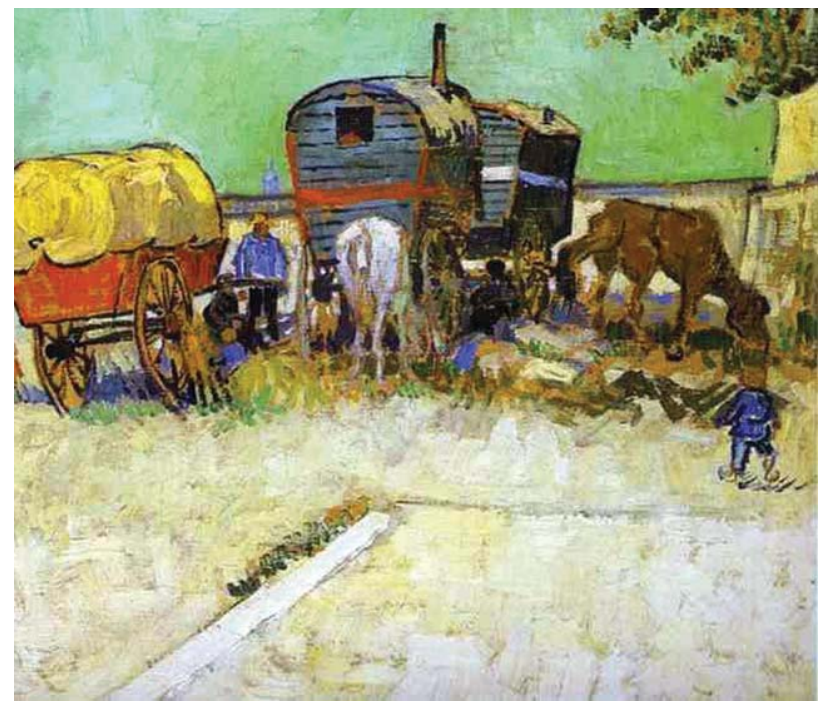

Figura 2. Vincent van Gogh: Campamento de gitanos cerca de Arles. Óleo sobre tela; 1888. 